\title{
Hausa Calligraphic and Decorative Traditions of Northern Nigeria: From the Sacred to the Social
}

\author{
Mustapha Hashim Kurfi \\ African Studies Center, Boston University \\ mustapha@bu.edu
}

\begin{abstract}
In the past, sacred Islamic calligraphies were used strictly in sacred places, whereas profane calligraphies were used in secular spheres. However, the trend now among some Hausa artists is to extend the sacred Islamic calligraphic tradition to the social domain. Some Hausa calligraphers do so by "desacralizing” their Islamic-inspired calligraphies. This article deals with the extension of Islamic decorations to secular social domains in Kano, Northern Nigeria. Such works are produced by calligraphers like Sharu Mustapha Gabari. I show how Hausa calligraphers like Mustapha Gabari creatively extend their arts, talents, and skills to other social domains. These domains include the human body, clothing, houses, and other objects. This article describes the ways in which the sacred and the secular realms overlap, and illustrates some key processes of enrichment the Islamic arts have undergone in sub-Saharan Africa. These processes exemplify the 'Ajamization of Islamic arts in Africa, especially how sub-Saharan African Muslims continue to creatively appropriate and enrich the Islamic calligraphic and decorative traditions to fit their local realities and address their preoccupations.
\end{abstract}

\section{Keywords}

'Ajamization - Calligraphy - Hausa - Decoration - Sacred - Desacralized - Enrichment

* I am indebted to Professor Fallou Ngom for introducing me to the field of 'Ajamī studies and for his unalloyed support to the realization of this volume. I also want to express my profound gratitude to Professors Steve Howard and Scott Reese; Dr. Jennifer Yanco; Zahra Suleiman; Emily Williamson; the blind reviewers of my article; and to the organizers as well as the participants to the ISITA Symposium Sacred word: The Changing Meanings in Textual Cultures of Islamic Africa, in honor of Late Sheikh John O. Hunwick, held at Northwestern University (Evanston, IL) in April 2016. 


\section{Introduction}

The centrality of the Qur'ān to the Islamic faith and its status as divine revelation mean that for generations, Muslims have made copies of their scripture that are as fine as their resources permitted. ${ }^{1}$ This is certainly true of the Hausa calligraphic and decorative tradition. Hausa is the largest ethnic group in Nigeria and one of the largest in the African continent. Schwerdtfeger argues that the religion of Islam found a very rich and varied cultural tradition in Hausaland, with a large variety of patterns being used to decorate not only houses but also tools and clothes. ${ }^{2}$ This is an indication that there is a strong relationship between Hausa decorative tradition and the religion of Islam. As Mazrui has noted, Africa demonstrates that it is easier to change a man's conscience than a man's taste - conscience being part of ethics, taste part of aesthetics. Aesthetics is the universe of beauty and ugliness, sometimes the world of the pleasant and the unpleasant. ${ }^{3}$

In the past, Hausa artists applied sacred calligraphies strictly to sacred spaces such as mosques and Islamic schools while they applied profane calligraphies to secular buildings. In contemporary times there has been a transformation. Calligraphies that are sourced from and inspired by sacred Islamic traditions are desacralized. ${ }^{4}$ They are now extended to other aspects of social life. In every day parlance, sacred means all Godly things - things that are religious and have spiritual value, whereas the secular refers to all things worldly - everyday things having little or no connection with God. In this article, the sacred is used with particular reference to the Qurān as the potent word of Allah. The secular, on the other hand, refers to attitudes or things that have no clear religious or spiritual function. The sacred/secular binary that many scholars use repeatedly does not reflect lived experiences of many Africans, especially Muslims such as the Hausa. In Hausaland, the sacred and the secular realms overlap in very interesting ways as reflected in local decorations and art.

Hausa artists may use some inscriptions for sacred purposes such as decorative boards for Qurānic graduation, decorations on mosque walls, and

1 James David, “The Master Scribes: Qurāns of the 1oth to 14th Centuries AD”, The Nasser D. Khalili Collection of Islamic Art, Vol. II (1992), p. 11.

2 Schwerdtfeger Friedrich, Hausa Urban Art and Its Social Background: External House Decorations in a Northern Nigerian City, London, International African Institute, 2007, p. 251.

3 See Mazrui Ali, "Islam and African Art: Stimulus or Stumbling Block?", African Arts, 27/1 (1994), p. $5^{0 .}$

4 By desacralizing I mean that the sacredness of the texts is removed or de-emphasized. 
other religious texts. They may also desacralize them by extending such decorations to other social spheres of their daily lives. These include making trophies as symbols of recognition for specific achievements; for ceremonies such as birthdays, weddings, or naming and coronation ceremonies and; for promotions or honors given to outstanding members of society, etc. The calligraphy used in these circumstances is secular. They may draw certain motifs from handwritten copies of the Quraan or other religious texts and apply them to different social domains. ${ }^{5}$ These include buildings such as palaces, walls, and other important sites, royal regalia, clothing embroidery, hats, carpets, bed sheets, tables, necklaces, veils, calabashes, cushions, robes, textiles, baskets, jewelry, as well as women's hand and feet via decorative henna designs (Lalle).

I argue such extensions of the Islamic calligraphic tradition to the social domain exemplify tangible dimensions of what has been recently called the "Ajamization of Islam." 'Ajamization as used in this paper refers to the various enrichment processes of Islamic calligraphy and arts that result from the co-articulations between Islam and local Hausa tradition. The 'Ajamization processes in Hausa society transcend orthography and extend to arts and calligraphy - the style of writing that is intended to be decorative. ${ }^{7}$ Although, decorative traditions can include calligraphy as well as mural designs, paintings, and pictures, I use calligraphy to refer specifically to the visual art related to writing. First, I provide an overview of the Hausa calligraphic traditions. Second, I examine the various types of Hausa Islamic scholars and their position in society, delineating the various forms of their works and their functions. Third, I present a case study centered on the work of the modern Hausa master calligrapher, Sharu Mustapha Bala Gabari, showing how his worldview influences his artwork. I then describe the materials, methods, and tools that he uses in his calligraphy. Finally, I offer suggestions for further research.

5 For details about the various patterns, motifs and inscriptions that Nigerian Muslims, particularly the Hausa professional calligraphers use, see Rene A. Bravmann, African Islam, Co-published by Smithsonian Institution Press and Ethnographica, 1983, especially chapter six: Islamic patterns - a penchant for beauty and privacy, pp. 88-101.

6 For more on the 'Ajamization framework, see Fallou Ngom, Muslims beyond the Arab World: The Odyssey of 'Ajami and the Muridiyya, Oxford Scholarship Online, 2016, especially pp. 17-20.

7 Andrea Brigaglia and Nobili Mauro, "Central Sudanic Arabic Scripts (Part 2): Barnāwī", Islamic Africa, 4/2, (2013), pp. 195-244. 


\section{The Study of Religion, Calligraphic Traditions, and Islamic Arts}

A scholar of the sociology of religion, Penny Edgell, criticizes recent scholarship on religion for neglecting non-Western Catholic and non-Christian religious practices, noting that religious identity, beliefs and practices have been taken for granted as strong and unitary influences on social action. ${ }^{8}$ Furthermore, another scholar of anthropology of religion, Stephen Palmié, challenges key premises regarding the stability of social science knowledge by questioning how scholars and practitioners are involved with the continual "cooking of history" - that is, via the formation of their own object of study. ${ }^{9}$ The above criticisms call for decolonizing mainstream theories and methods that have dominated current scholarship and practice by studying non-Western religious beliefs and practices, including Islam in sub-Saharan Africa.

Similarly, a curator for the British Museum's collection of ethnographic objects and textiles from the Middle East and Central Asia, Fahmida Suleman, notes that studies of Qurānic manuscript illumination and calligraphy dominate all other published works related to the artistic expression of the Qur'ān. Many of the largest collections of Islamic manuscripts are held in the Muslim world and most of the chief collections are published in one form or another. Yet, many of them remain understudied. ${ }^{10}$ This can be attributed to a number of factors, including some scholars' lack of proficient knowledge in local languages. For instance, in Islamicate societies and precisely in Islamic Africa, many religious texts are written in African languages such as Hausa, Yoruba, Wolof, Mandinka, and Pular, etc. using the Arabic script ('Ajamī) in addition to Arabic. The lack of knowledge of these African languages has resulted in misunderstandings of the contents and forms of many African 'Ajamì texts. This led to a neglect of these important sources of knowledge that offer a unique entry into local cultures, as well as the intellectual traditions, belief systems, and artistic production of many African Muslims.

Along the same line of thought, Ngom notes that the political and academic emphasis on Muslims in the Arab world (Mashriq - Middle East; Maghrib North Africa) and on their literature written in Arabic has often resulted

8 Edgell Penny, "A Cultural Sociology of Religion: New Directions," The Annual Review of Sociology, 38 (2012), p. 263.

9 Palmié Stephen, The Cooking of History: How Not to Study Afro-Cuban Religion, Chicago, Chicago University Press, 2013. See specifically the introduction and chapter three on syncretism.

$10 \quad$ Fahmida Suleman, "Introduction," Word of God, Art of Man: The Qur'ān and Its Creative Expressions, Selected Proceedings from the International Colloquium, London, 18-21 October 2003, ed. Fahmida Suleman, Oxford University Press, p. 3. 
in the neglect of the rich body of religious, historical, and secular insights available in the texts of Muslims who do not live in that part of the world." The literatures of many of these Muslims were recorded both in Arabic and in the indigenous writing traditions of their languages using the modified Arabic script systems collectively known as 'Ajamī. The important contributions of 'Ajamì to the spread of religion in the world cannot be over-emphasized. 'Ajamì has been a vehicle for the expansion of Islam in sub-Saharan Africa. ${ }^{12}$ Christian missionaries also used it for purposes of proselytizing. For example, some missionaries published the Holy Bible in 'Ajamī in order to reach out to Hausa and Fulfulde masses. ${ }^{13}$ Several other studies show that 'Ajamī served as an engine for Muslim women's education, civic engagement and for challenging political power. ${ }^{14}$ 'Ajamī literature, despite its potential for broadening our

\section{Ngom, Muslims Beyond the Arab World, p. 3.}

12 For important references on African "Ajamī traditions, see Ngom, Muslims beyond the Arab World, 2016; Mervyn Hiskett, A History of Hausa Islamic Verse, London, School of Oriental and African Studies, 1975; Matt Schafer, “'The Pakao Book": Expansion and Social Structure by Virtue of an Indigenous Manuscript," African Languages, Vol. 1 (1975), pp. 96-115; Murray Last, The Sokoto Caliphate, London, Longman, 1977; David Robinson, "Literature in Arabic Script," History of Africa, Vol. 9, (1982), pp. 251-261; Neil Skinner, Hausa Readings, Wisconsin, The University of Wisconsin Press, 1996, pp. 103-159; El-Miskin Tijjani, "The 'Ajamī tradition in Borno: Theoretical Considerations on Its Binary and Unitary Forms," Paper presented at the Conference on the History of 'Ajamī before the Jihad, at the Center for the Study of Nigerian Languages, Bayero University, Kano -Nigeria, 28-3oth December, 1989, pp. 6-9; Muhammad Sani Umar, "Education and Islamic Trends in Northern Nigeria: 1970s-190os," Africa Today, 48/2 (2001); Nikolai Dobronravin, "Literacy among Muslims in the 19th Century Trinidad and Brazil," in Slavery, Islam and Diaspora, ed. Mirzai, B.A. Montana, I.M. and Lovejoy, Trenton, African World Press, Inc., 2009, pp. 217-236.

13 See Deftere Futtorde (The Book of Genesis in Fulfulde 'Ajamī). n.d. Hosted at Yale 'Ajamī Collection; and Littaafin Farawa (The Book of Genesis in Hausa 'Ajamī) at the African 'Ajamī Library at Boston University: http://dcommon.bu.edu/handle/2144/11727. Also see Abdu Injiiru and Murray Decker, "Living Letters: The Script as a Redemptive Bridge in Reaching Muslims," International Journal of Frontier Missiology, Vol. 29/2 (2012), p. 79. 'Ajamī

14 On civic engagement, see Beverly Mack, Muslim Women Sing: Hausa Popular Song, (African Expressive Cultures), Indiana, Indiana University Press, 2004; Jean Boyd and Beverly Mack, One Woman's Jihad: Nana Asma'u, Scholar and Scribe, Indiana, Indiana University Press, 2000; and Jean Boyd and Beverly Mack, Educating Muslim Women: The West African Legacy of Nana Asma'u, 1793-1864, Oxford, Interface Publications, 2013. For the use of 'Ajamī to challenge to challenge French colonial rule, see Sana Camara, "Ajamī Literature in Senegal: The Example of Sëriñ Muusaa Ka, Poet and Biographer," Research in African Literatures, 23/ 3, (1997), pp. 179-181. On other profane uses of 'Ajamī, see Fallou Ngom, 
understanding of Muslim Africa, has been only partially studied by scholars, and more often than not, for linguistic purposes neglecting the social sphere..$^{15}$ The calligraphic and material culture and how their meanings change over time are important dimensions that need to be investigated.

African arts cannot be understood without investigating the spiritual and philosophical underpinnings of the works. ${ }^{16}$ The bracketing or silencing of the voices of the African master calligraphers obscures the artists' intentions. It results in misunderstanding their agency by assuming they do their work only for profit-motives. Such a perspective, which is based on rational-economic choice theory, further increases the prejudices and stereotypes about professional artists in sub-Saharan Africa. These false assumptions have provided the foundations for research and policy formulation that continue to have an impact on the arts and the status of Muslim calligraphers in Africa.

\section{Islam, Hausa Islamic Scholars and Professional Calligraphers}

Religion is a crucial force deeply embedded in African societies. This led Toyin Falola and Nana Akua to suggest that it is the reason why in many African languages there is no word for religion. ${ }^{17}$ In Hausa, for example, religion is called Addini (from Arabic: al-dīn). Religion is embedded in daily life, and as such no special word is required for its description. It routinely deals with issues concerning food production, festivals, chieftaincy, disease, invasion, as well as life transitions and rites of passage such as birth, puberty, marriage, and death. ${ }^{18}$ Among sub-Saharan Africans, whether they are followers of "traditional" religions, Islam or Christianity, the sacred and the secular overlap. Each profane act is considered intertwined with the sacred. This is also true in Islam where every act of the Muslims is expected to be guided by Islamic dictates. ${ }^{19}$

"Murid 'Ajamī Sources of Knowledge: The Myth and the Reality," in From Dust to Digital: Ten Years of the Endangered Archives Programme, Cambridge, UK, Open Book Publishers, 2015, p. 364 .

15 Hamid Bobboyi, "Ajamī Literature and the Study of the Sokoto Caliphate," in The Meanings of Timbuktu, ed. Shamil Jeppie and Souleymane Bachir Diagne, Cape Town, SA, 2008, p. 123 .

16 Bolaji Campbell, Painting for the Gods: Arts and Aesthetics of Yoruba Religious Murals, 2007, Trenton, NJ, Africa World Press, Inc., p. 1.

17 Toyin Falola and Nana Akua Amponsah, Women's Roles in Sun-Saharan Africa, Greenwood, Santa Barbara California, 2012, pp. 81-82.

18 Ibid.

19 See particularly the translational meaning of Süra al-An'am (The Cattle), Qurān, chapter 6:162-163, which teaches that Islam is a complete way of life. 
Prior to the arrival of Muslim traders and missionaries from North Africa in what is today Northern Nigeria, the Hausa had developed a highly bureaucratized state structure. When Muslim traders and teachers began arriving in the twelfth century, they were incorporated into an already highly stratified and specialized society. Primarily based in Northern Nigeria and southeastern Niger, the Hausa people constitute a diverse ethnolinguistic group with rich cultural traditions. A significant number of Hausa also live in Nigeria's immediate neighboring states (Cameroon and Chad), and beyond in countries such as Ghana, Togo, Senegal, Gabon and Sudan. Today, with over 50 percent of the country's population who are Muslim, Nigeria has the largest Muslim population in West Africa. ${ }^{20}$

Nigeria's population is estimated at 182 million people. ${ }^{21}$ Of these, over 90 million are Muslims, located mainly in the country's Northern region. They are predominantly Sunnī who adhere to the Malikī School of jurisprudence. As noted earlier, Islam is traditionally conceived as an all-pervasive worldly and religious system that rejects a clear separation between secular and religious aspects of life. The sacred interacts with the secular in many important ways. The Western dichotomy between 'religious' and 'secular' therefore poses a problem when applied in the contexts of pre- and modern Islamic cultures. ${ }^{22}$ Thus, studying the blending of the sacred and the secular in the Hausa calligraphic tradition is an important way to understand the role Islamic scholars play in the enrichment of Islamic arts in Northern Nigeria.

The Kanuri people were the pioneers in the "linguistic domestication" of the Arabic alphabet in Nigeria. ${ }^{23}$ Their influence on the Hausa literary and calligraphic tradition was due to a number of reasons. The Borno Empire, particularly in the seventeenth century, was a center of Islamic scholarly excellence and a model for the Hausa. Many Hausa Qurānic scholars either studied in Borno or their mentors or mentors' mentors had studied with Borno scholars. The Borno people were famous for their well-organized Tsangaya system - centers of learning specializing in Qurānic education - a system that

$20 \quad$ See Pew Research Center, "Mapping The Global Muslim Population," (2012). Available online: http://www.pewforum.org/2009/10/o7/mapping-the-global-muslim-population23/.

21 The cIA World Fact Book, 2016.

22 Doris Behrens-Abouseif, "Beyond the Secular and the Sacred: Qurānic Inscriptions in Medieval Islamic Art and Material Culture," in Word of God, Art of Man: The Qur'ān and Its Creative Expressions, Selected Proceedings from the International Colloquium, ed. Fahmida Suleman, Oxford University Press, 2013, p. 41.

23 Hamid Bobboyi, "Relations of the Borno Ulama with the Sayfawa Rulers: The Role of the Mahrams," Sudanic Africa, 4 1993), p. 198. 
persists in Hausaland. Local scholars developed and sustained Islamic learning in Borno. The reputation of learnedness among Borno scholars attracted large numbers of students and provided a stable basis for the conduct of educational activities during the Saifawa reign ${ }^{24}$ and beyond (1470-1808). ${ }^{25}$ Relevant to our discussion is the 'Ajamization of aesthetics, which encompasses the local tradition of writing the sacred Qurān along with its calligraphic traits, geometrical patterns, decorative markings, and other marginalia, and how these initially sacred elements are transformed into everyday use.

Among the Hausa people, the character of the cleric is represented by the Malam, or Islamic scholar. ${ }^{26}$ Within the social hierarchy of Hausa society, Malamai (Islamic scholars) are second only to the Saraki (aristocrats), followed by the Attajirai (the rich) and lastly, the Talakawa (the commoners). In a study of arts and Islamic literacy among the Hausa of Northern Nigeria, Salah Hassan categorizes the Malams or Malamai into two major groups: The Malaman Qur'āni and the Malaman Ilmi. The Malaman Qurāni are scholars who are experts in the memorization of the Qur'ann. The Malaman Ilmi are those who are experts in other areas of Islamic knowledge, especially jurisprudence. ${ }^{27}$ However, further classifications can be made within the Malaman Qurāni group that Hassan identified. There are those who have memorized the entire Qurān by heart (Hafizai plural for hafizi). There are also those who are not necessarily Hafizai but who are highly knowledgeable in the Qurān and serve as Islamic calligraphers who are locally called Masu Zayyana. There are also those who are both Hafizai and Masu Zayyana, as well as individuals who are Hafizai, Masu Zayyana and tutors and trainers in calligraphy. The latter produce complete handwritten copies of the Qurān and give them to publishers

24 Saifawa or Sefuwa dynasty is the name of the emirs, kings, or rulers (the mai) of the Kanem-Borno Empire. It was initially centered in Kanem in western Chad, and later in present-day Borno (north-eastern Nigeria). For details, see Smith Abdullahi, "The Early States of the Central Sudan", in J. Ajayi and M. Crowder (Hg.), History of West Africa, 1/1, (1971), pp. 158-183.

25 Ibid, 198-9.

26 For details about how the Malamic tradition emerged from the Kanuri empire, see El-Miskin Tijjani, "The 'Ajamī Tradition in Borno: Theoretical Considerations on its Binary and Unitary Forms," Paper presented at the Conference on the History of 'Ajamì before the Jihad at the Center for the Study of Nigerian Languages, Bayero University, Kano, Nigeria, 28-30th December, 1989.

27 Salah M. Hassan, Art and Islamic Literacy among the Hausa of Northern Nigeria, Lewiston, N.Y., E. Mellen Press, 1992, p. 2. 
who reproduce them as market editions. They are engaged in the reproduction and transmission of the knowledge and skills of calligraphy. This last category is the focus of this research. ${ }^{28}$

Writing a complete copy of the Qur'ān is not something every scholar has the ability to do though it is each one's wish. Yet, even among Hausa writers and copyists, not all are calligraphers. Muslim calligraphers occupied the apex of a pyramid of specialized labor and trade connections. ${ }^{29}$ It has been argued that one of the factors that necessitated the reproduction of handwritten copies of the Qur'ān was unavailability of printed books in Arabic. ${ }^{30}$ Calligraphy has never been challenged as the supreme art of the Islamic world. ${ }^{31}$ It is among the oldest and most revered arts in Islam. Having emerged during the faith's first century, it grew and flourished at the apogee of its civilization. Then, in the course of time, the early tradition of Qur'anic calligraphy was replaced by the cursive styles still in use today. ${ }^{32}$ Understanding calligraphic designs and writings found on manuscripts, charms, amulets, Qur'ānic boards, and architectural decorations embody and visually represent three interrelated domains: artistic traditions, literacy, and magical and folk healing practices. ${ }^{33}$

The Hausa people of Northern Nigeria have high regard for calligraphy and decoration. They believe that the two perform important functions in society, including fostering Hausa identity, social cohesion, and cultural continuity. Within domains such as religion, politics, law, entertainment, education, and decoration, traditional Hausa art: (1) promotes the perpetuation of communal association; (2) serves as technology; (3) attracts people's attention and reforms

28 Zayyana is the Hausa term for calligraphy. Mai Zayyana is singular while Masu Zayyana is plural. It is an Arabic loanword from Zeena or Tazyeen. The market editions are lithographed or (more commonly) xeroxed copies of handwritten samples, produced for wide distribution and market sale. For details see John O. Hunwick, "Accessing the Islamic Intellectual Tradition in Africa: The Arabic Literature of Africa Project (ALA)," http:// www.sum.uio.no/research/mali/timbuktu/research/articles/ala_inkroad.pdf (accessed December 28, 2016), 9 .

29 David J. Roxburgh and Mary McWilliams, Traces of the Calligrapher: Islamic Calligraphy in Practice, C. 1600-190o, Houston, The Museum of Fine Arts, 2007, p. 7.

$30 \quad$ Ismaheel Akinade Jimoh, "The Art of Qurānic Penmanship and Illumination among Muslim Scholars in Southwestern Nigeria," in Word of God, Art of Man: The Qurān and its Creative Expressions, Fahmida Suleman, ed., Oxford University Press, 2003, p. 175.

See Marcus Fraser and Will Kwiatkowski, Ink and Gold; Islamic Calligraphy, London, Sam Fogg Museum für Islamische Kunst, Berlin, 2006.

32 Alain George, The Rise of Islamic Calligraphy, Berkeley, California, Saqi Books, 2010, p. 13.

33 See Hassan, Art and Islamic Literacy, 1992, pp. 21-27. 
their attitudes; (4) promotes conceptual knowledge; (5) provides entertainment and; (6) helps maintain social reality and enhance human aspirations. ${ }^{34}$

Over the centuries, the Hausa have demonstrated that they are both flexible and cohesive. They assimilated easily to Islam, incorporating those aspects of it that enhanced their traditional culture and making adjustments for those that did not. ${ }^{35}$ Examples of Islamic aspects that were easily appropriated include calligraphy and decorative traditions. Islam served as a stimulus for creative calligraphy. ${ }^{36}$ The Hausa of Northern Nigeria, particularly Kano, are famous for the production and use of calligraphy and decorations in both sacred and secular realms.

In the sacred realm, they are famous for writing market editions of the Qurān, poems, books of jurisprudence, decorative wooden tablets, amulets, and so forth. They use both Arabic and 'Ajamī and utilize their innovations and

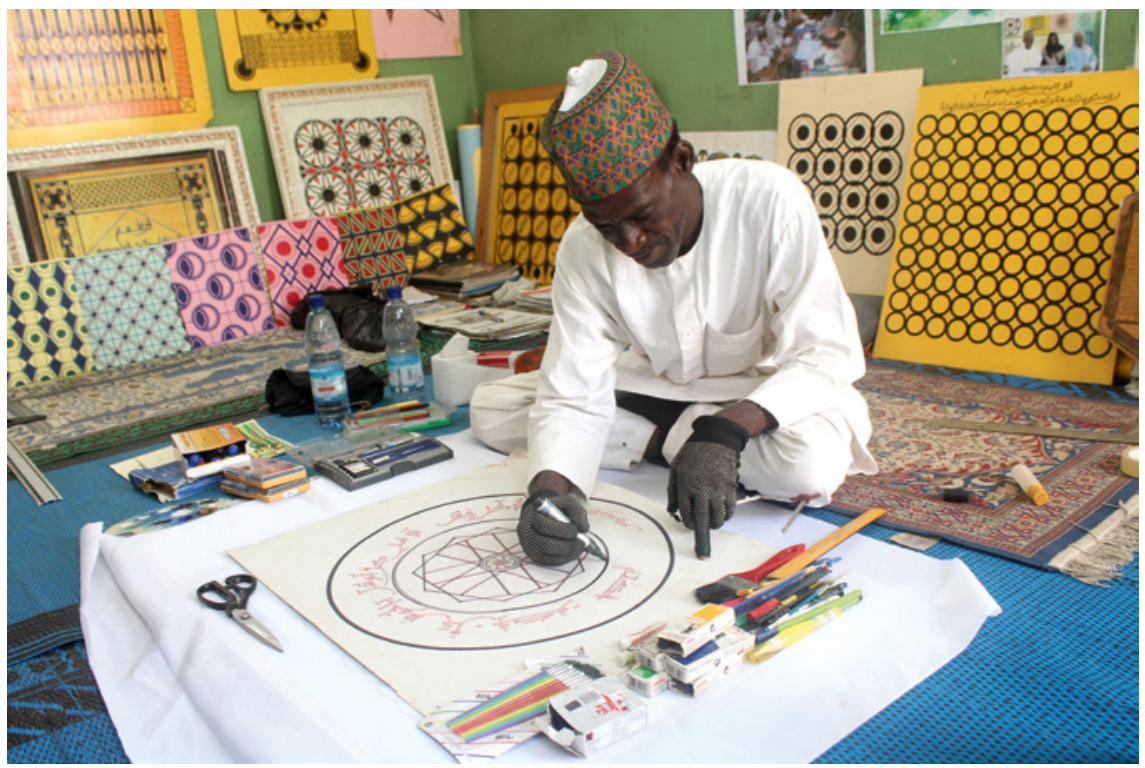

FIGURE 1 The Hausa Calligrapher-Sharu Mustapha Bala Gabari.

PICTURE TAKEN BY THE AUTHOR IN KANO, DECEMBER, 2015.

34 Rufus Boboye Fatuyi, "The Social Functions of Selected Nigerian Masks and Hausa Wall Decorations: Implications for Contemporary Nigerian Education," Ph.D. Dissertation, University of Wisconsin-Madison, 1980, p. ix.

35 See Barbara Callaway and Lucy Creevey E., The Heritage of Islam: Women, Religion, and Politics in West Africa, Boulder, Colorado: Lynne Rienner Publishers, 1994, p. 9.

36 Ali A. Mazrui, "Islam and African Art: Stimulus or Stumbling Block?", African Arts, 27/1, (1994), p. 50. 
creativity to transform locally produced raw materials into finished products of calligraphy and decoration. In the social realm, they use decorations that originate from Islamic art on clothing, houses and walls, calabashes, horses, camels, and other objects. It is upon this background that I examine the work of the contemporary Hausa calligrapher, Sharu Mustapha Bala Gabari.

\section{A Modern Hausa Calligrapher: Sharu Mustapha Bala Gabari}

Sharu Mustapha Bala Gabari was born in the Gabari ward of metropolitan Kano. Now in his mid-40s, he was born to a well-known and well-respected learned family that has produced many Qur'ānic memorizers, writers and calligraphers. His father is the renowned Sharif Mu'azu, popularly known as Sharu Bala Gabari, who has produced as many as 63 handwritten copies of the Qurān. Sharu Bala is "the past master of the Arabic calligraphic tradition of Kano."37 Like his father, Mustapha was nurtured in the traditional circles of local Qurānic craftsmen that included teachers, scribes, amulets makers, booksellers, and wooden board decorators, among others. But unlike his father, Sharu Mustapha's point of departure is utilizing his arts, talents, and skills to extend sacred calligraphies into other social domains. Brigaglia and Nobili have highlighted the role Sharu Mustapha's father played in mediating a wider transition from a traditional scribal culture to a calligraphic one. ${ }^{38}$ Sharu Mustapha drew inspiration from his father who served as his mentor. He explained to me how he "moves" or transits from producing sacred texts and other secular calligraphic designs that originate from Islamic arts to modern geometry. ${ }^{39}$ He explains how he combines his knowledge of geometry with his other skills to produce a unique hybrid form of modern Hausa calligraphy:

The Prince Charles School of Traditional Arts in the U.K. came to know of my work and my institute. In the year 2006, they came to engage me and some of my trained students in geometry and how to utilize it and advance our practices. Prince Charles with his entourage came to Kano and witnessed what I was doing. He was amazed and encouraged me to

37 Brigaglia, "Central Sudanic Arabic Scripts (Part 1): The Popularization of the Kanawı script", Islamic Africa, 2/2 2011, pp. 51-85

38 Brigaglia and Nobili, "Central Sudanic Arabic Scripts, 2", pp. 196-7 and footnote 4.

39 I am using the term "movement" because Sharu Mustapha has not abandoned the production of sacred materials in Arabic and 'Ajamī. Instead, he produces them in tandem with the desacralized "secular" ones. But evidently, he now seems to be more preoccupied with the mass production of the secular pieces than the sacred ones. 
keep [up] the good job. The goemetry has exposed me to learning new methods particularly in precision. But that does not make us abandon our Hausa calligraphic tradition. ${ }^{40}$

Sharu Mustapha explains not only how he came to modern geometry, but also his position vis-à-vis maintaining the status quo. He provides justification for doing so by asserting that he wants to retain originality in his work. He notes that he inherited Islamic scholarship and calligraphy not only from his father, but also from his great grandparents. As such, he wants to sustain the tradition and train a group of young scholars for continuity, self-reliance, prestige and power. His basic knowledge of Islamic mathematics, training in geometry and his background in Islamic jurisprudence, particularly the sciences of collection and disbursement of Mìräth (inheritance disbursement) and Zakāt (required Islamic charity), have facilitated his production of unique calligraphic designs. ${ }^{41}$ This corroborates Bravmann's assertion that the highly refined world of Islamic mathematics and geometry are intertwined. Both fields of creativity share common methods and dispositions. They equally demand clarity of vision, precision of thought and considerable organizing capabilities. Bravmann notes that the artist and mathematician literally became one in the Islamic civilization. ${ }^{42}$

It is important to note that Sharu Mustapha Gabari has produced Hausa 'Ajamì materials in both sacred and secular forms. Many of the sacred materials are copies of figh (Malikī figh such as kitāb al-Akhdarī, kitāb al-qawāid al-Is(amī), religious elegies, and other devotional texts. His non-sacred materials include notebooks with Hausa 'Ajamī inscriptions often with images for personal use and for politicians; programs or announcements for government civil servants; and others for private use (souvenirs for wedding, naming ceremonies, and other social functions and events). One factor that has influenced Sharu Mustapha is his travel around the world, including Saudi Arabia, North Africa, Asia, and Europe. While his father took advantage of the location of Kano, Sharu Mustapha took advantage of his travels around the world which revealed to him the power of his work.

With this background, Sharu Mustapha has established trust among the people around him. As noted earlier, he hails from a well-respected learned family. He is a Häfiz (some one who has memorized the Qurān), an educator, a

40 Interview with Sharu Mustapha Gabari in Kano, December, 2015.

41 The science of sharing inheritance and Zakāt disbursement requires one to be good at calculations (some basic knowledge in mathematics). 
mentor, and someone who has established and retains a wide social network. Thus, he is regularly invited to participate in conferences, seminars, and workshops where his skills are continuously honored. With this background, Sharu Mustapha was able to establish a modern school, register it with the Corporate Affairs Commission, and run it with the technical support and advice of Professor Abdallah Uba Adamu, the Vice Chancellor of the National Open University of Nigeria. The Institute of Calligraphic and Geometric Designs is located in Gabari, Kano Municipal Council. It is completely private and receives no funding from the government. Currently, the institute through its Board of Trustees is making efforts to be certified by the National Board for Technical Education as an Innovative Vocational Institute (IVI) in order to gain accredited status so that it can award certificates to student. The institute has trained 2,257 male and female students in sacred and secular calligraphy and geometric designs since its establishment in 2011.

\section{The Calligrapher's Materials, Methods, and Tools}

To make beautiful writing, you must possess - in addition to knowledge and talent - the materials, and tools, such as pen, paper, and ink. Each of these has its own special importance in producing beautiful writing and material harmony. ${ }^{43}$

Beyond the years of training and practice required to master the varied Arabic scripts used in Northern Nigeria, Hausa Islamic calligraphers must learn Hausa 'Ajamī, its vocalization and the science of colors. They also need to spend time producing the pens, ink, and colorants required for their art, and learning to modify and refine these materials for particular purposes and effects. Decorated Qurāns are valued in West Africa, as elsewhere in the Muslim world, and those produced in Borno and Kano are among the most distinctive. In addition to their calligraphic traits, they exhibit unique geometrical patterns for $r u b^{c}$ divisions (a quarter of the Qur'ān), usually filling a whole page, and smaller sajdah (prostration), and hizb (one-sixtieth of the Qur'ān) and juz' (one thirtieth of the Qur'ān) markers are always made with a combination of black, red, yellow and green inks. ${ }^{44}$ The tools, supplies, and equipment that calligraphers do not produce on their own are typically obtained from a variety of artisans,

43 Mahmud Bedreddin Yazir 1893-1952, cited in Roxburgh and McWilliams, 2007, p. 9.

44 See Brigaglia Andrea, "Arabic Manuscripts from West Africa: A Catalogue of the Herskovits Library Collections", Digital Library of Northwestern University, available online at: http://digital.library.northwestern.edu/arbmss/historical.html. 
including blacksmiths, cutlers, papermakers, gold beaters, gilders, wire drawers, ceramicists, and makers of pen cases, kits, bags or boxes. ${ }^{45}$

Given his extensive resources, Sharu Mustapha does not seem to have difficulty accessing the appropriate materials needed to produce his calligraphies. He confirms that the various colors of ink he uses are locally produced and that they have comparative advantages over the imported ones. For instance, the locally produced ink gives far better results with long lasting fadeless attractive impressions. He adds that patrons or customers easily identify the differences between the local and the foreign ink in terms of quality, preferring the local product. The importance of the quality of ink in writing has been emphasized in the literature. Imamuddin notes that the beauty of writing depends very much on the ink. ${ }^{46}$ Hausa Muslim scholars, and by extension calligraphers, utilize varieties of ink that are locally produced. The most common of the ink colors is black, which the calligrapher produces from local ingredients such as charcoal, the bark of certain trees and leaves, maize or millet, sugar and salt. Other common colors include red, yellow, green and orange. Important to our discussion is how he makes the ink by himself rather than purchasing it from craftsmen who specialize in the business.

When asked why he prefers producing his own ink rather than purchasing ready-made products, Sharu Mustapha Gabari notes that it was because producing it by himself offers him the opportunity to make the best to his satisfaction. He notes that recently Nigerians have begun importing Chinese-made inks but the products are never close to the quality of the locally produced ones and are also very expensive. Thus, despite the influence of globalization, Hausa calligraphers generally favor utilizing their traditionally sourced raw materials for their art. This corroborates Brigaglia's finding that the Hausāwī versions of the handwritten Qurān, which are reproduced as market editions, use local items, integrating as few "global" influences as possible. ${ }^{47}$ On the color application, Sharu Mustapha Gabari notes that it is a specialized knowledge that one needs to spend time to acquire. One needs to know what each color stands for and where it should be applied.

Figures 2 and 3 show some of the tools Sharu Mustapha uses to produce his calligraphies and decorations. Figure 2 shows the traditional Hausa calligraphic instruments, which include different types of pens and various colors of ink. What is important about the pens is that they are of different sizes

\footnotetext{
45 See Roxburgh and McWilliams, Traces of the Calligrapher, 2007, p. 13.

46 See Sayyid Muhammad Imamuddin, Arabic writing and Arab Libraries, Westport, Connecticut: Greenwood, 1983, p. 23.

47 Andrea Brigaglia, "Central Sudanic Arabic Scripts (Part 1), p. 54.
} 


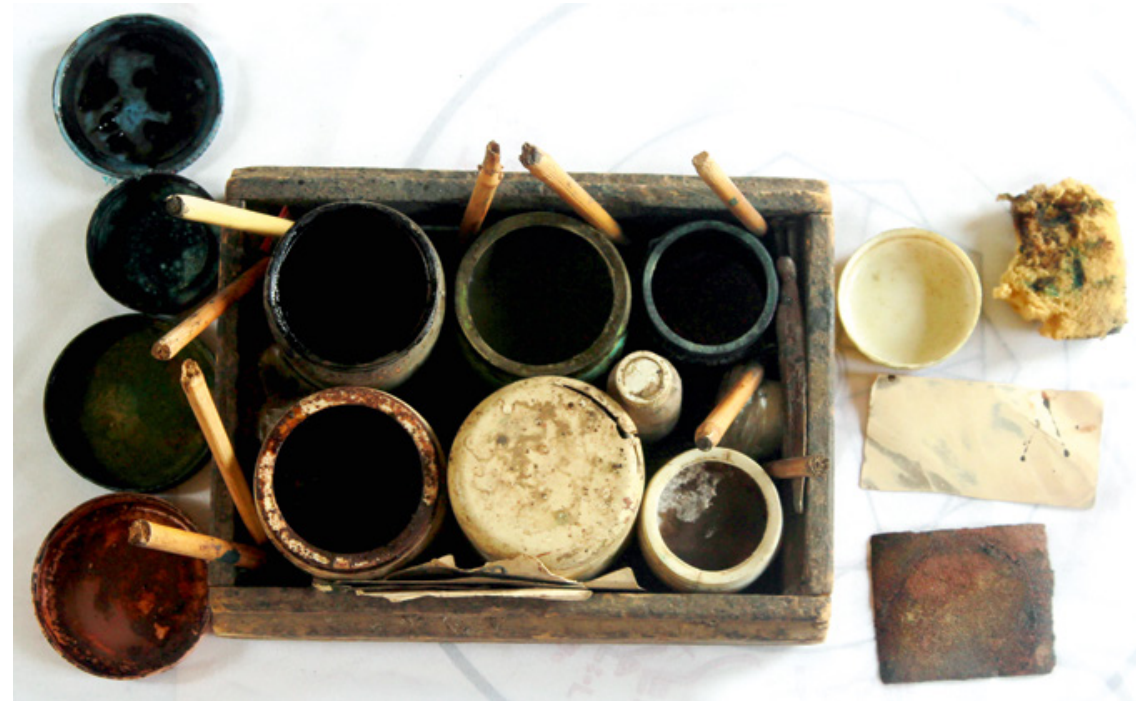

FIGURE 2 Hausa calligraphic traditional materials.

РНОTO BY THE AUTHOR.

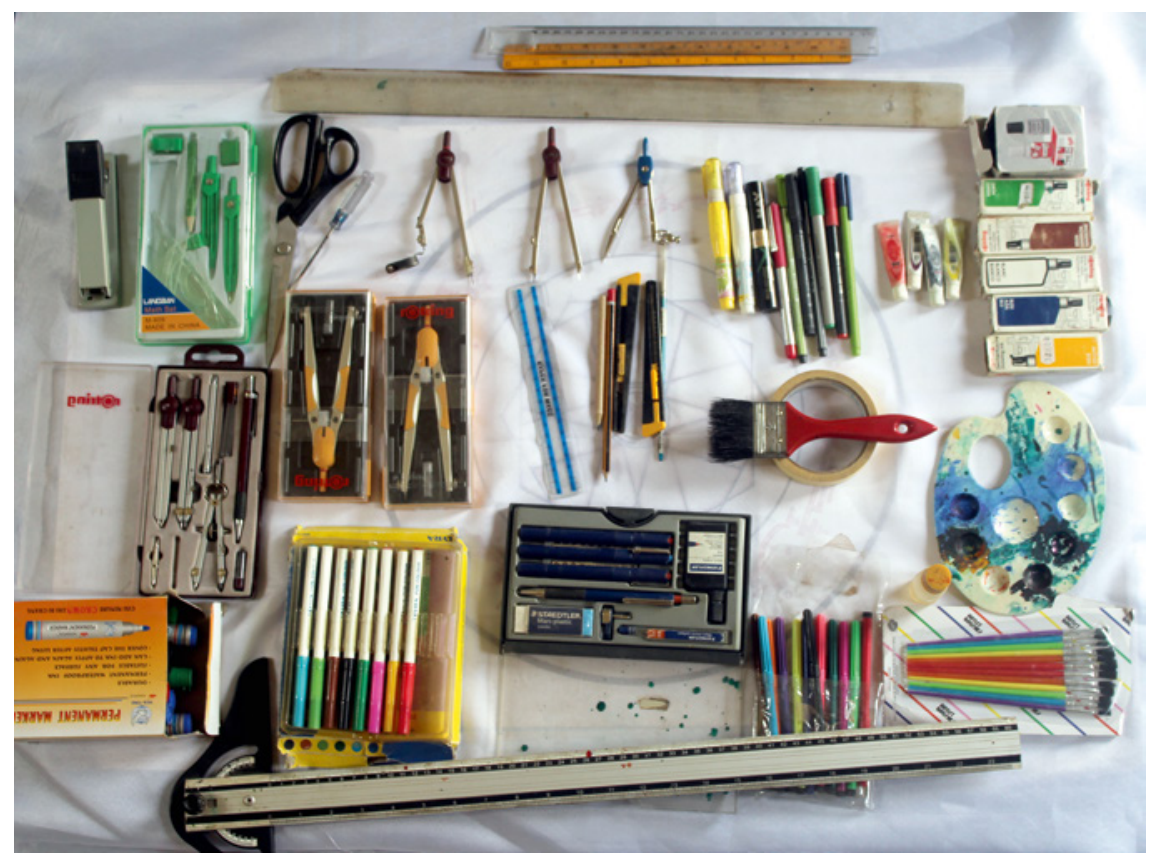

FIGURE 3 Modern materials.

PHOTO BY THE AUTHOR. 
and shapes, each one performing a particular function. A pen made with flat head produces thicker writing called Zube compared to the one with a pointed head, which produces thinner writing called Jibge. While specific kinds of pens are used only for vocalization, there is another category that is used for applying different colors (mainly black, red, green, and orange). On the other hand, Figure 3 shows the modern geometric tools that Sharu Mustapha uses in his work. They include compass, pencils, erasers, pencil sharpeners, roller-tip pens, permanent markers, rulers, protractors, and different types of ink with various colors. It is striking how Sharu Gabari blends his geometric and calligpaphic skills to innovatively create new designs and styles. It is also interesting how he transmits these skills to his disciples-male and female-exposing them to various areas of specialization such as architecture, embroidery, henna designs, men's hats, curtains, and so forth.

Concerning his methods, Sharu Mustapha notes in our interview that there are thousands of designs that come to his mind and he hardly ever reproduces the same design twice. ${ }^{48}$ In other words, he believes that he is endowed with the talent and skills to come up with different designs tailored to each client. His sources of inspiration come from his manifold experiences-the training and mentorship he received from his father, the decorated wooden table that his father designed for him and gave to him as a "graduation certificate," the desire to fulfill a mission of cultural preservation of the Hausa calligraphic and decorative tradition, and the pleasure and satisfaction he gets in doing his work. He explains that there are numerous advantages in the calligraphic and decorative profession. One of the most important, in his view, is to fulfill a religious obligation. He believes that by doing his work he responds to the call of duty to exemplify the ethical values of discipline and humility while expressing the creativity and talent that God has bestowed on him. Sharu Mustapha asserts that he derives pleasure in transmitting his knowledge, skills and expertise to others, especially the younger generations of men and women. Worthy of note here is the master calligrapher's mindset and motive for his action.

Sharu Mustapha indicated to me that many of his calligraphic works are for women and that the majority of the beneficiaries of his training are female. ${ }^{49}$ Many trained women also train others and apply their skills to various forms of social life such as henna design, embroidery on clothes, hats, curtains, bed sheets, handbags, and shoes. It is common for one to be trained and to train others regardless of their literacy level. To acquire calligraphic skills one

48 Interview with Sharu Mustapha Gabari in Kano, December, 2015.

49 For a discussion on gendered arts and women's spaces of control, see Falola and Amponsah, Women's Roles, chapter five, "Women and the Arts and Literature," pp. 123-151. 
needs time for apprenticeship and practice. All of Sharu Mustapha's students that I encountered were literate and educated in the Western sense. Some had college degrees while others were attending high schools. Sharu Mustapha's school does not have any literacy prerequisites for enrollment. ${ }^{50}$ The language of instruction is Hausa, using both Hausa 'Ajamī and Latin scripts for lessons. Additionally, there are lessons instructors teach in English such as Basic English, Elementary Mathematics, and Geometry for beginners. The instructors take time to explain in Hausa for an effective learning experience. This is an effective means for improving functional literacy in both Hausa 'Ajamì and Latin scripts. The school also provides a hands-on vocational training to students. As such it is a local means of job creation for the youth in Kano.

Hausa arts and aesthetics as reflected in the work of Sharu Mustapha exemplify how Islamic traditions continue to be "Ajamīzed," localized and enriched by Hausa scholars in Northern Nigeria. Sharu Mustapha hopes that the apprentices he trains will produce unique and more sophisticated calligraphies. He believes that through his innovative work, he is making enduring contributions to his own society. These developments confirm Bravmann's argument that:

African Muslims did not assume the role of passive recipients of Islam but shaped the religion whenever necessary to fit local circumstances: a synthesis developed between the universalistic orientation of Islam and traditional beliefs and perceptions that proved vital and enduring. ${ }^{51}$

Figures 5 through 9 are samples of some of the decorated markings that the calligrapher Sharu Mustapha uses in his handwritten copies of the Qurān. Figure 4 is the decorated wooden tablet that Sharu Mustapha's father, Sharu Bala Gabari, wrote himself and awarded to Mustapha as his "graduation certificate" when he successfully memorized the entire Qur'ān in 1996. The writing on the decorated wooden tablet was Sharu Bala Gabari's calligraphic sample. As it can be seen in Figure 4, the calligraphy is distinct and used for a purely sacred purpose as reflected by the Qurānic verses of Süra al-Fätiha (The opening chapter of the Qurān). As Brigaglia notes, the key features that made Sharu Bala Gabari's calligraphy distinct include regularity and standardization, which many West African calligraphers purposely avoided. ${ }^{52}$ Sharu Mustapha's handwriting and calligraphic orientation strictly follows that of his father. His

\footnotetext{
5o This is one of reasons why the school seeks to be recognized as a Vocational Training Institute (VTI) by the National Board for Technical Education.

51 Bravmann, African Islam, 1983, p. 13.

$5^{2}$ Brigaglia, "Central Sudanic Scripts, Part 1," p. 80.
} 


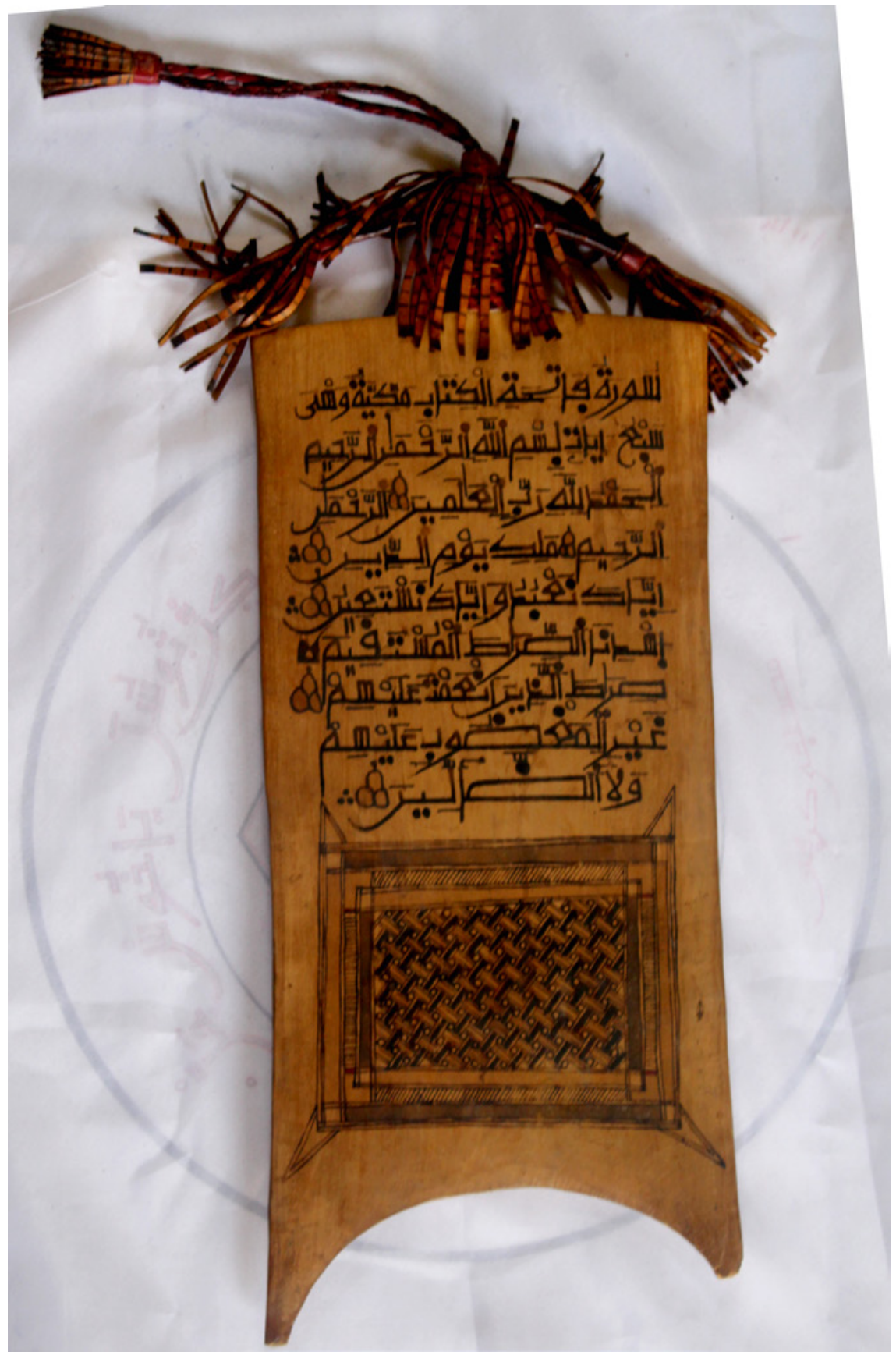

FIGURE 4 Sample of a decorated wooden tablet with inscription of Sūra al-Fātiha. PHOTO BY THE AUTHOR. 


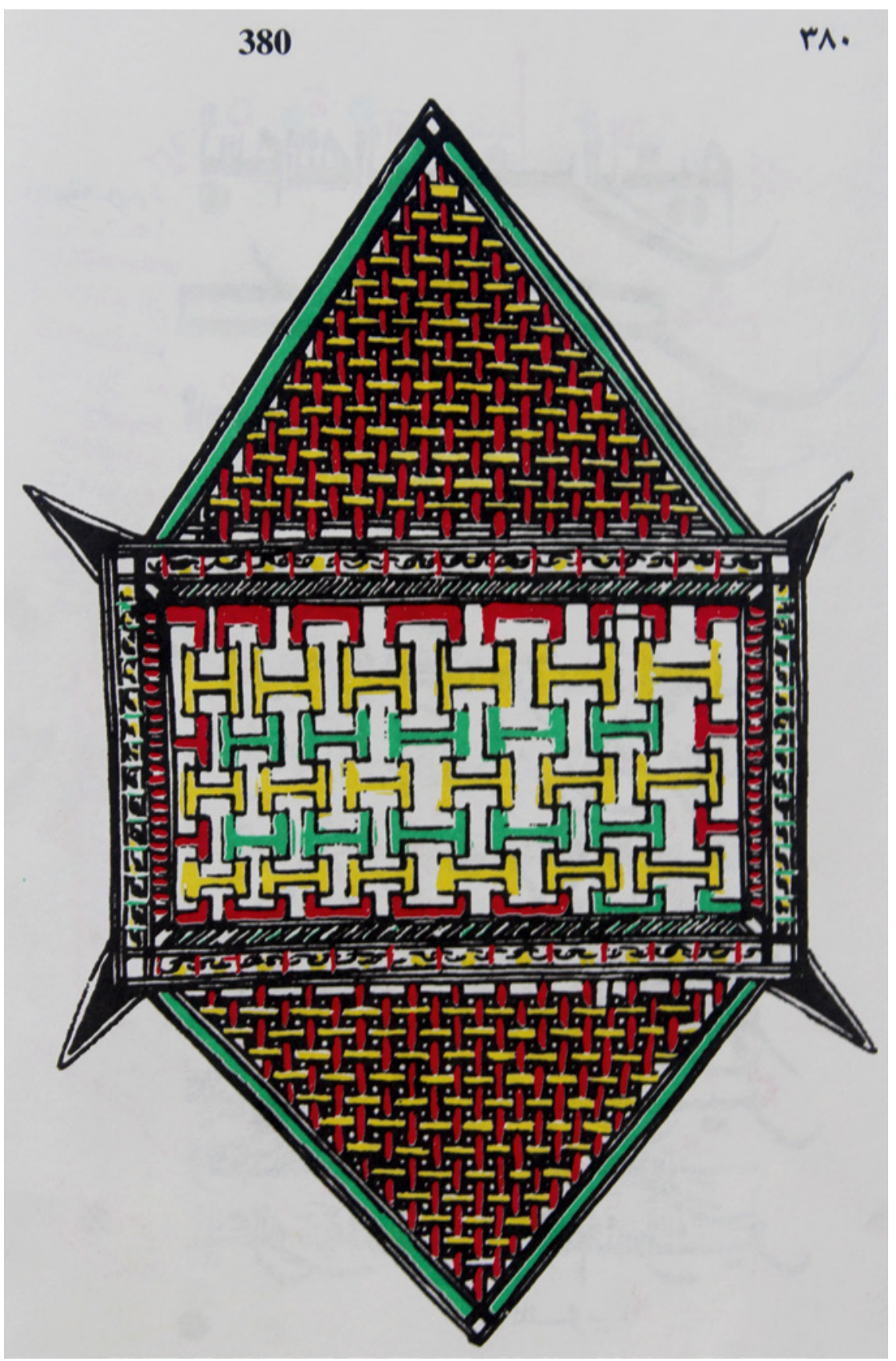

FIGURE 5 Sample of a decorative pattern marking the middle of the Qur'ān. PноTO BY THE AUTHOR. 


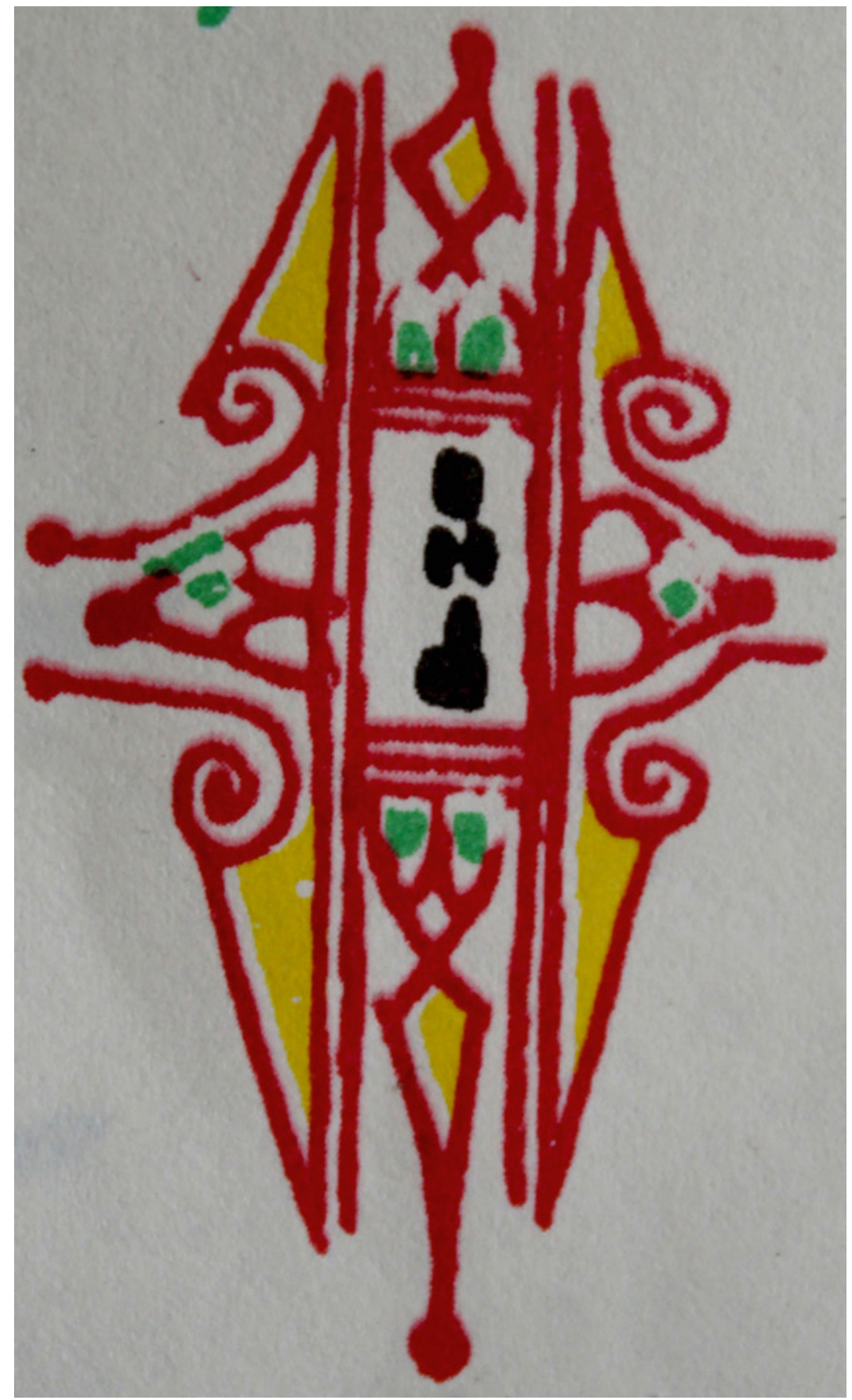

FIGURE 6 Sample of a decorative pattern marking a section, thumn (eighth of hizb), from the Qur'ān.

PHOTO BY THE AUTHOR. 


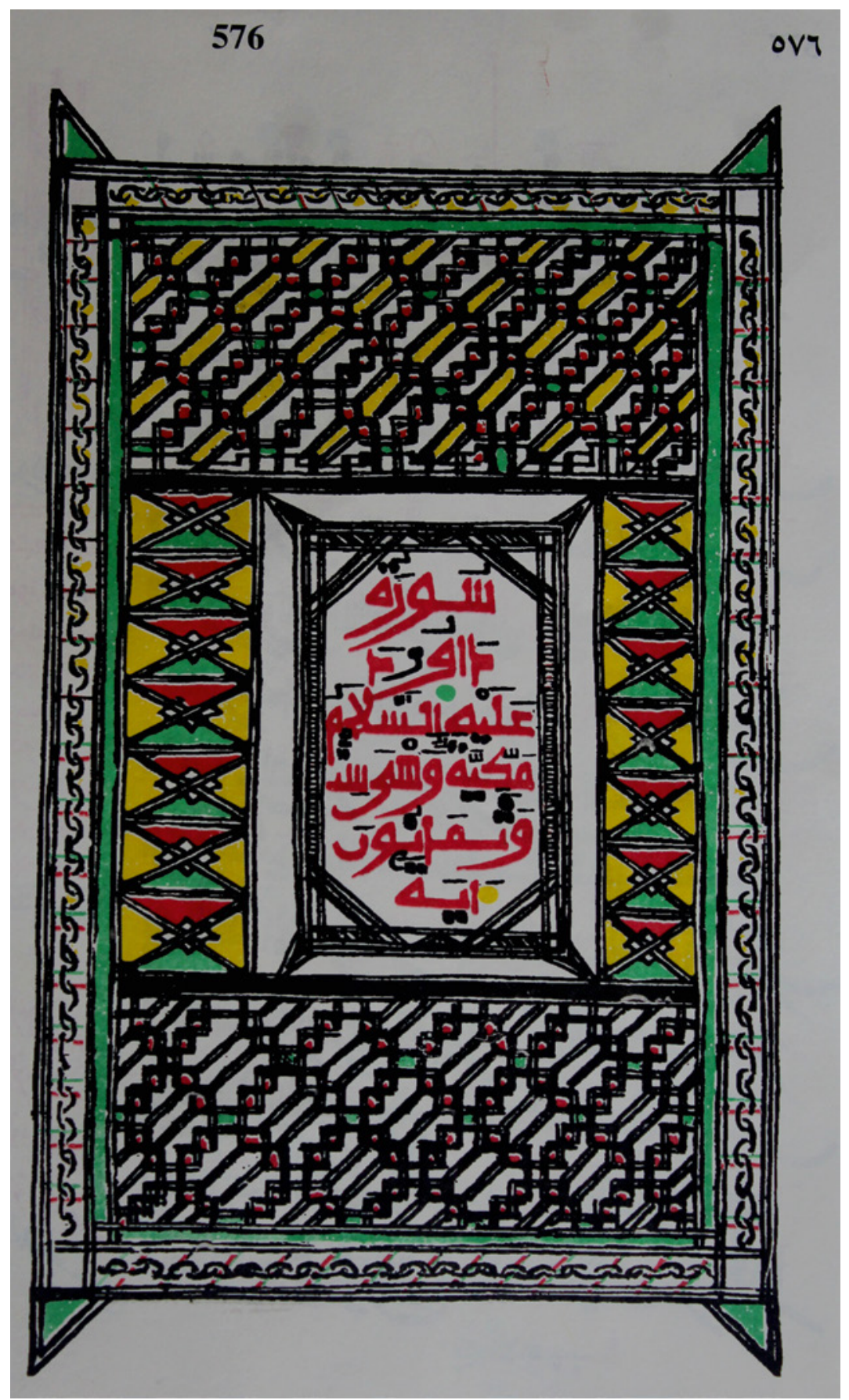

FIGURE 7 Sample of a decorative pattern mark introducing Sūra Dāwūd. PHOTO BY THE AUTHOR. 


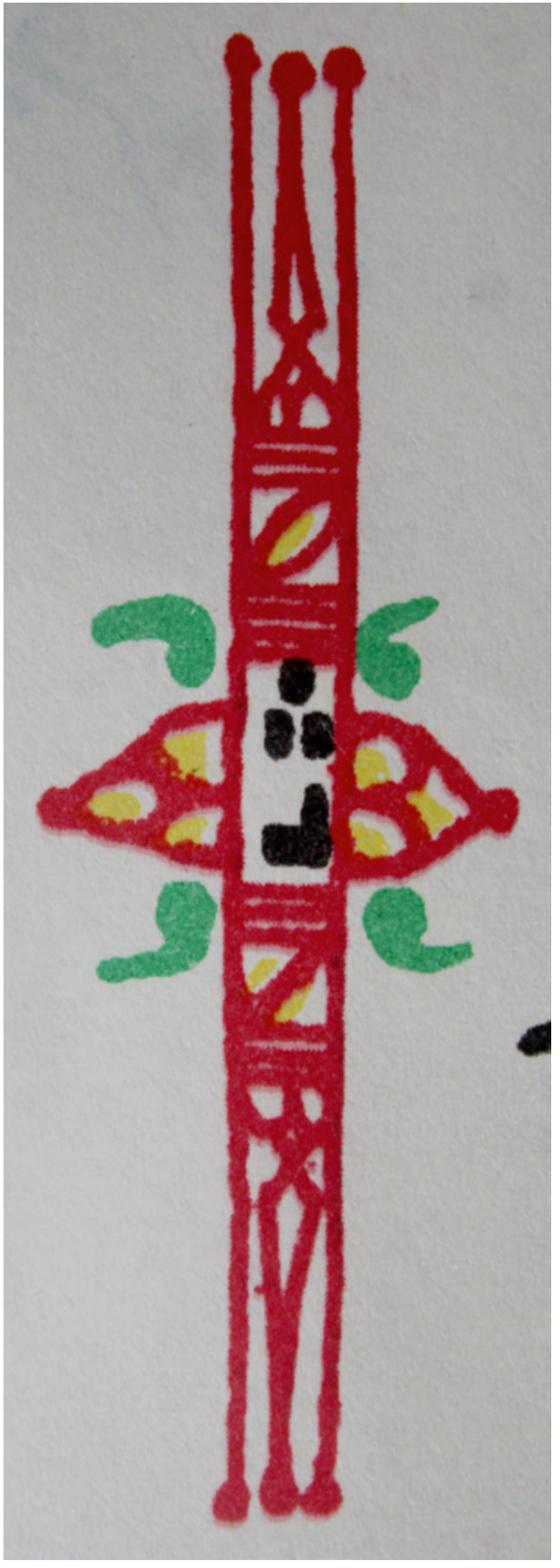

FIGURE 8

Sample of a decorative pattern marker indicating a section, thumn (one eighth of a hizb from the Qur'ān) - a motif mostly used on equestrian apparel, especially royal regalia. PHOTO BY THE AUTHOR. 


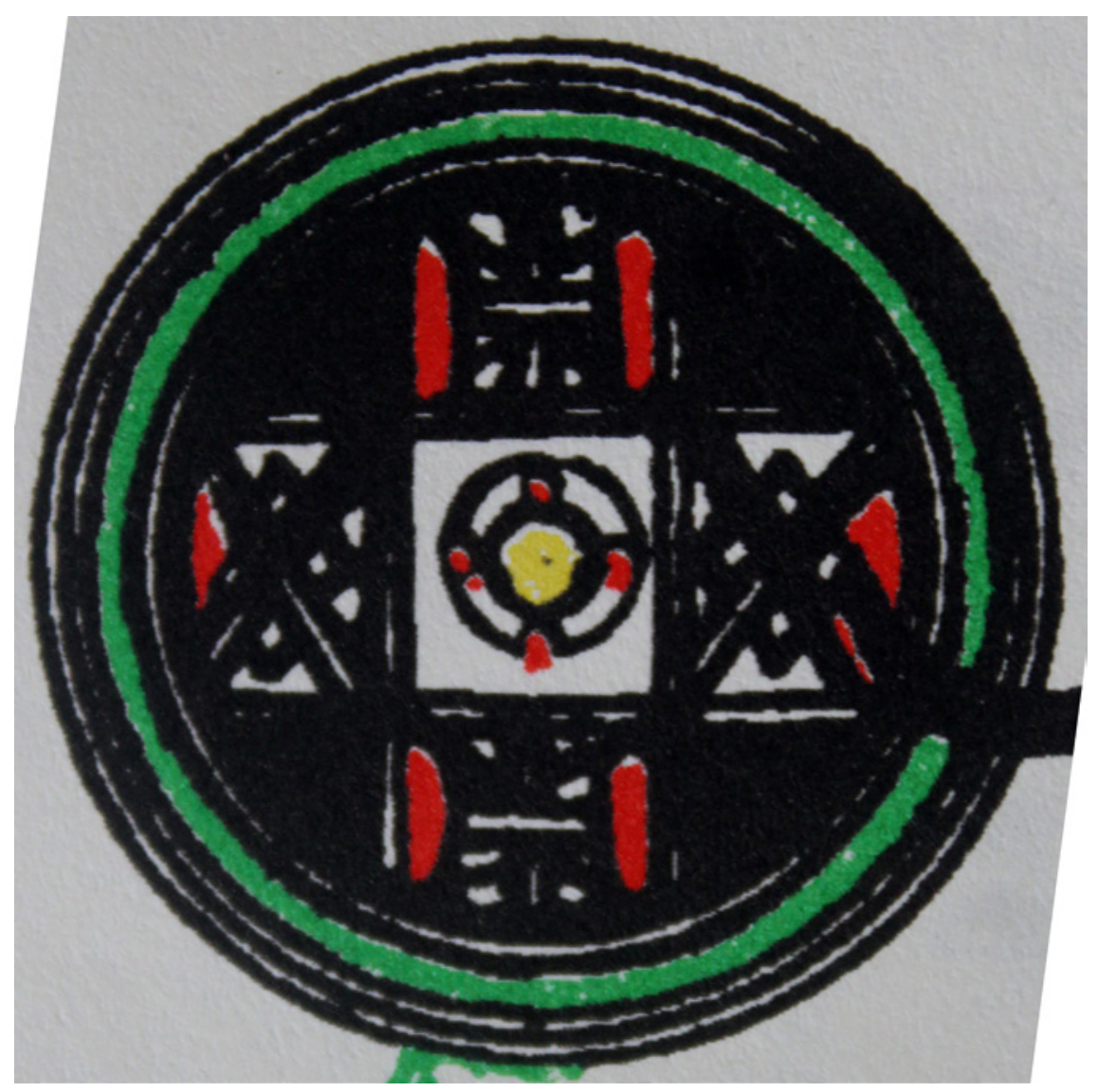

FIGURE 9 Sample of a decorative pattern - a hizb marker from the Qur'ān. PHOTO BY THE AUTHOR.

newly acquired skills in geometry and use of modern tools further enhance the regularity, angularity, and beauty of his calligraphic works. This is evident in both his sacred inscriptions as well as in his non-sacred calligraphies (as reflected in figure 11 below).

Figure 5 is a sample of a decorative pattern marking from Süra Maryam (chapter 19 of the Qurān), which is considered the middle of the Qurān. It portrays the beautiful artistic decorations that our scribe skillfully employs. Similarly, figure 6 is another sample of a decorative pattern marking of a section, thumn (eighth of hizb), which is recognizable by the Arabic letter tha $\bar{c}$. The use of this decoration is extended to secular commodities, particularly clothing or embroidery. Sharu Mustapha utilizes this motif and applies it to men's large embroidered gowns (Babbar-riga). This motif is popularly known as Kwado da 
linzami (stylish embroidery on the front and back of men's clothing). Sharu Mustapha also uses this decorative pattern on women's embroidery, curtains, and bedsheets. There are various styles of this decorative pattern applied to clothes and even buildings. Figure 7 is yet another elaborate decorative pattern which marks the beginning of Sūra Dāwūd. The use of a more elaborate artistic design such as the one in figure 7 at the beginning of a chapter means that it has a special meaning. Sharu Mustapha extracts many artistic designs and styles from this motif and applies them to the social realm. For instance, he applies the blocks and interlocks that make up the frame to come up with designs for decorative purposes, including necklaces, earrings, hand rings, and the textile industry. Parts of the decorative pattern in figure 7 are also used on the walls of some mosques, palaces and important buildings for aesthetic purposes.

Furthermore, figure 8 is a decorative pattern marker that indicates a section, thumn (similar to figure 6), recognizable by the Arabic letter tha $\bar{a}^{\mathrm{c}}$. The only difference lies in the artistic decoration used and in "statistical details" about the sacred text. ${ }^{53}$ For figure 8 , the motif has a totally different shape with less decoration compared to the one in figure 6 . Sharu Mustapha mostly uses this motif in equestrian apparel, especially royal regalia. The regalia associated with Hausa equestrians include horse and camel gear, blankets, and other regalia. The Kurmi market in Kano is famous for producing most of the attire that the emirs and traditional horse riders use during the durbar. Many of the apparel producers ask Sharu Mustapha Gabari to distinguish theirs by customizing them with peculiar motifs. Additionally, figure 9 is a hizb marker from the Qurān. As noted earlier, there are 6o hizbs in the Qurān and each marker is differently designed with certain variations in artistic decorations. From the design in figure 9, Sharu Mustapha Gabari adopts, modifies, and applies the motifs in a variety of things, ranging from calabashes, baskets, men's hats, carpets, veils, to henna designs on women's hands. This is particularly due to the shape-circular nature of the motifs. Critical here is the motif by the side within the circle, which appears to be the Hausa Mai-Dagi (the Star of David) which holds special significance for both the Hausa and non-Hausa peoples in Northern Nigeria. ${ }^{54}$

53 The "statistical details" consist of counting the chapters, divisions of sections, frequencies of clauses, phrases, words, and occurrence of verses in the Qurān.

Mai-Dagi is considered the Northern Knot or Northern Symbol (Tambarin Arewa), and has special place among many, including clerics producing Talismans. On the practices of talisman manufacturing in a West African center of Islamic learning, see Geert Mommersteeg, "Léducation coranique au Mali: Le pouvoir des mots sacrés", in L'enseignement islamique au Mali, ed. Louis Brenner and Bintou Sanankoua, Bamako:Jamana, 1991, 45-61. 
Central to our concern here is the changing meaning of these pieces. Though these patterns originate from sacred sources and were initially used for religious and spiritual purposes, they also assume new non-religious and non-spiritual meaning. Based on the assessment of the images above, it is clear that the dimensions in these images cannot fully be appreciated without closely examining their origins and the relativity of their meanings and how they change over time. One way to appreciate both their aesthetic value and meanings is by accessing the actors' (calligraphers') minds, asking the right questions. In order to have a nuanced understanding of the symbolisms embedded in the motifs that calligraphers apply whether for sacred or non-sacred use, one needs to understand their motivations.

Based on my assessment, there appears to be no special instructions or norms on how to use or apply motifs and the style in the handwritten Quràns among the Hausa people of Northern Nigeria. This is because the motif and the style used depend on the calligrapher's expertise and discretion. Yet, bigger, more creative geometric decorative motifs are usually used as markers in particular designated places such as the beginning of the Qur'ān at Süra al-Fātiha, at the beginning of Süra al-Baqarah, at the center or middle of the Qurān (the end of Süra al-Kahf, which is equally the beginning of Süra al-Isra'), as well as the last part of the Quràn. Other distinctions are made at the various positions that determine recitation rules: hizb; nisf; rub; khums; sudus; and thumn. These calculations and decorative markers are usually accompanied by letters that represent each category such as the letters tha $\bar{a}^{\prime}$ for thumn, and $r \bar{a}$ for $r u b^{\complement}$, and so on. ${ }^{55}$ It is worth noting that Sharu Mustapha applies all of the motifs from the sacred calligraphies to various social domains.

\section{More Extensions: From Sacred Calligraphy and Decoration to the Social}

As noted earlier, one distinguishing feature of Sharu Mustapha Gabari's calligraphy is appropriating and utilizing his skills, knowledge of Islam, and life experiences while integrating modern geometry and applying it to the social realm. Sharu Mustapha has received training in Islamic knowledge. He is a respected Qurānic teacher, scribe, and professional calligrapher among the people of Kano. Yet, he thought of extending his sacred calligraphies into the social realm. The domains of his calligraphy therefore become unlimited. Only a few will be examined here. Hausa culture values aesthetics and demonstrates

For details, see Brigaglia, “Central Sudanic (Part 1)”, p. 69. 


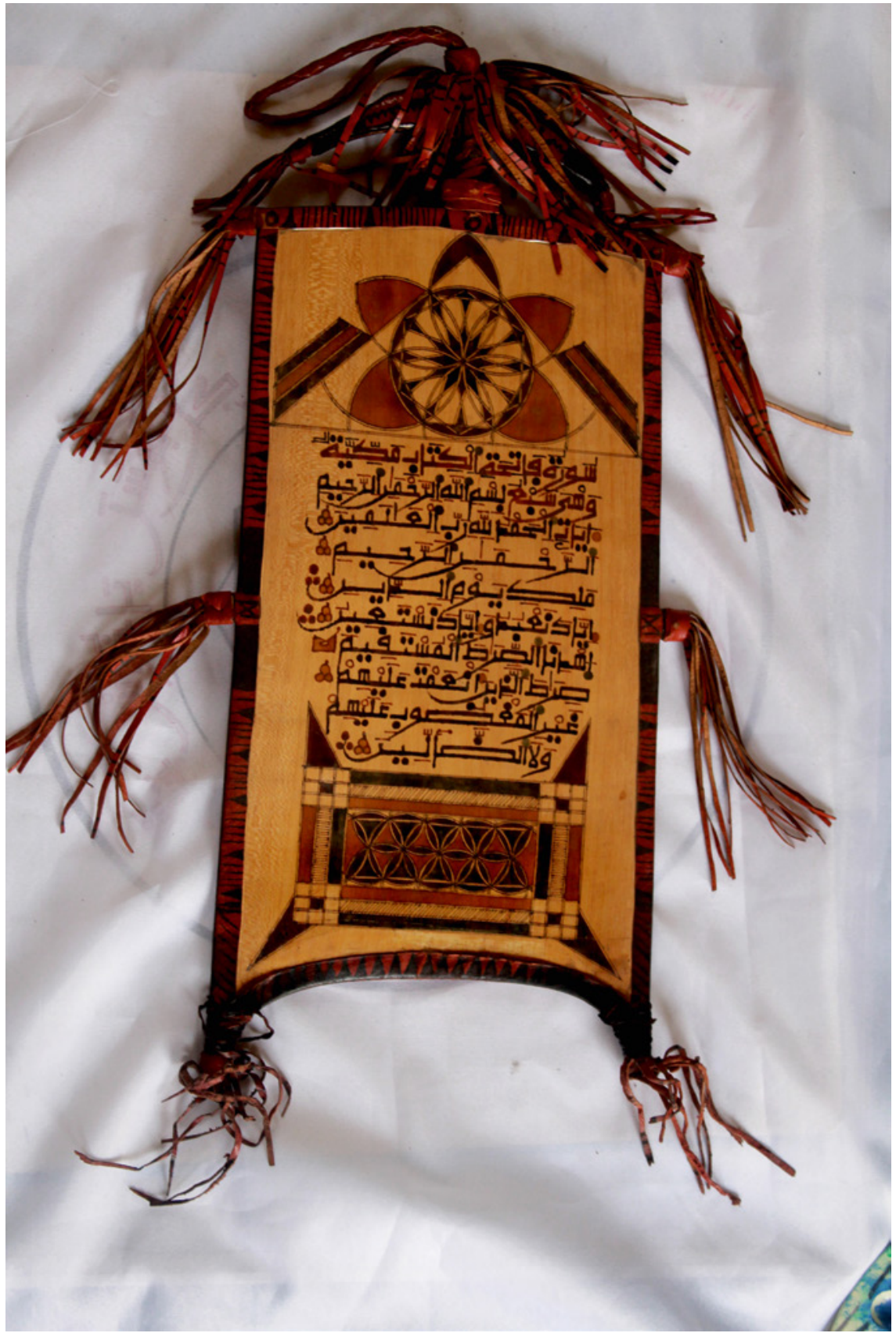

FIGURE 10 Sample of a decorated wooden tablet with inscription of Sūra al-Fātiha. PHOTO BY THE AUTHOR. 


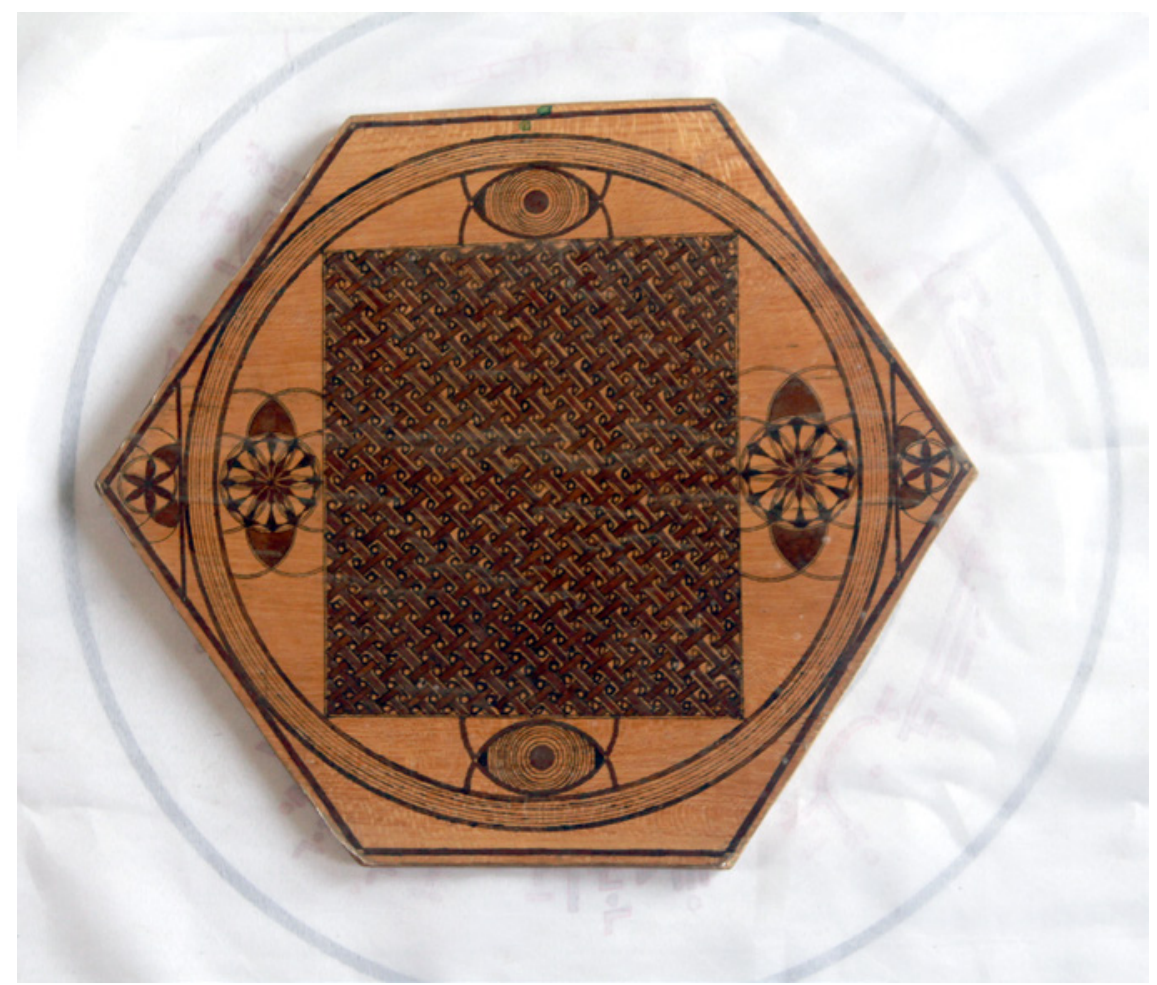

FIGURE 11 Sample of a decorative desacralized gift item "trophy." РНОTO BY THE AUTHOR.

that in wall decorations, and in embroidered clothing for animals such as horses. These are displayed especially during durbar festivals. The embroidered clothes are markers of identity as well as symbols of power and prestige. ${ }^{56}$

Figure 10 illustrates a traditional decorative wooden tablet similar to the one that Sharu Mustapha received from his father during graduation. At its center is inscription of Sūra al Fatiha (the opening chapter of the Qurān) written

$5^{6} \quad$ For an extensive discussion about dress and status in the Sokoto caliphate, the gender dimension of decorative textile production, and the role of decoration as sign of power in royal houses as a source of identity and pride, see Colleen Kriger, "Textile Production and Gender in the Sokoto Caliphate", The Journal of African History, 34/3, (1993), pp. 364-7; Colleen Kriger, "Robes of the Sokoto Caliphate", African Arts, 21 (1988) pp. 54-57; and for details regarding how members of the Hausa aristocracy organized their own dress and that of their horses to express their identity, see Judith Perani and Norma Hackleman Wolff, "Embroidered Gown and Equestrian Ensembles of the Kano Aristocracy", African Arts, 25 (1992), pp. 70-81. 
in Arabic. But the one in (Figure 11) is a desacralized version used for nonsacred purposes. Sharu Mustapha made it using his skills in geometry. Sharu Mustapha noted that he and his students make less fancy ones for their wider public. The more elaborate ones, he notes, are made as gifts for prominent dignitaries including Emirs, governors, senators, philanthropists, as well as important personalities such as Prince Charles who visited Nigeria in 2006. By not using Arabic letters in figure 11, Sharu Mustapha follows the desacralization practice that Ngom described. Sharu told me that he desacralizes such art works for the general public's social use. He added the following statement: "everyone can freely use our products without any doubt about the content and contexts. This has paid off because there is a tremendous increase in the demand [for] these products. ${ }^{57}$

Another way the Hausa calligrapher under study innovatively extends his ideas from the sacred to the social is in buildings. The art of decorating houses is an old tradition in Hausa societies, but is now receiving revived attention among the public. This is attributed to a number of factors, including local calligraphers' skills and ability to creatively transfer their decorative talents from Qurānic texts to other social spheres such as the front of houses and important historic sites.

The last aspect that I examine is the traditional henna (Lalle) decorative design, which is a purely female practice in Hausa society. Though, in some societies such as India, there are male henna artists who practice their work on women, in Hausa tradition, women are generally the only artists and they only work on women. Though he does not perform his work on women, Sharu Mustapha has developed numerous henna designs informed by motifs from his Qurānic decorations with some modifications tailored to the needs and tastes of women. He makes numerous templates of these designs and sells them to women. He has even trained many young women on how to develop their own designs and be self-reliant. He encourages them to train others as he trained them. Sharu Mustapha envisions a society in which people's talents are nurtured and Islamic calligraphic and decorative traditions flourish. ${ }^{58}$

57 Interview with Sharu Mustapha Gabari, December 2015 .

$5^{8}$ For more details on the relationship between religious values and economic growth, see Elke de Jong, "Religious Values and Economic Growth: A Review and Assessment of Recent Studies", in Religion and Development: Ways of Transforming the World, ed. Gerrie Ter Haar, New York, Columbia University Press, 2011, p. 119; Jean-Philippe Platteau, "Religion, Politics and Development: Lessons from the Lands of Islam", Center for Research in the Economics of Development, University of Namur, 2007, (Unpublished paper); and $\mathrm{Mu}-$ hammad Yunus, Banker to the Poor: Micro-lending and the Battle against World Poverty, New York, Public Affairs, 1999, p. 78 and 107-111. 


\section{Conclusion}

This article has examined the changing meanings of Hausa calligraphy and decorations, with a particular reference to the work of Hausa Islamic calligraphers in Kano, Northern Nigeria. These artists utilize their talents and skills to extend sacred Islamic arts to other social domains using modern tools. These domains include clothes, buildings, bodies, and other objects. The paper demonstrates how the sacred and the secular overlap in important ways and how the line separating the two is blurry in Hausaland and Muslim Africa at large. The extension of religious Hausa calligraphy and decorative traditions from the sacred to the social realms discussed throughout the article are tangible aspects of the 'Ajamization of Islamic arts in Hausaland. These aspects of the 'Ajamization of Islamic arts include the ways in which Hausa Muslim calligraphers and decorators appropriated and enriched their works drawing on their traditions, modern realities, and worldviews. Though Hausa Muslim calligraphers and decorative artists are influenced by their fellow Muslims in the Arab world, they also retain their traditional decorative patterns and appropriate Islamic arts, which they creatively extend using modern tools beyond sacred domains. These developments exemplify the significance of religion and the tight nexus between sacred and secular realms in Hausa society and Muslim societies at large.

This study shows how a neglected aspect of Hausa professional calligraphers' work can illuminate and deepen our understanding of Islamic African art beyond formal analysis. It appreciates previous works that focused on the economic, political, social and religious aspects of the Hausa calligraphy and decorations and complements them by incorporating the insights and motivations of a famous artist, Sharu Mustapha, who extends sacred calligraphies and decorations to other social spheres. The case of Hausa Muslim calligraphers like Sharu Mustapha is one of the many illustrations of the enrichment processes that the concept of 'Ajamization entails. The concept highlights the ingenuity of West African Muslims within the larger global Islamic culture. Many scholars have tended to view West African Islam as peripheral to the centers of Islamic learning and culture in North Africa and Arabia (the Arab world). This has led to the neglect of the African reception, interpretation, adaptation and transformation of introduced elements such as in writing, calligraphy, and arts. ${ }^{59}$ As Behrens-Abouseif noted, the predominantly secular character of 
inscriptions on everyday use seems to validate the notion of the exalted status of the written word of God, as stated in the Holy Book itself. This notion may have further implications for Islamic calligraphy and decoration in African and the Muslim world, pointing to the need to investigate the changing meaning of the sacred word. ${ }^{60}$

It is now apparent that religion is a growing force in public life in Africa, as in many other parts of the world and is connected to African Muslims' identity. ${ }^{61}$ Using art as an example, this article sheds light on more grounded, "in-place" understandings of how the social and the sacred are intertwined. The data show that Hausa calligraphers and decorators transcend the boundaries between the sacred and the secular. They desacralize their calligraphies and decorative designs by extending their use from the sacred to the social domain. There is much to be learned from investigating the calligraphic and decorative works of Hausa scholars in relation to other practices in Muslim Africa, including those of the Wolof, Mandinka and Swahili Arabic and 'Ajamī scholars, among others. There is also the need to further examine the interplay between the Maghribī and the other scripts in use in Muslim Africa, which have their own unique histories, geographical distribution, and 'Ajamized artistic forms.

6o Behrens-Abouseif, "Beyond the Secular", p. 47.

61 For more on this topic, see Gerrie Ter Haar, How God Became African: African Spirituality and Western Secular Thought, Pennsylvania, University of Pennsylvania Press, 2009, p. 209 and the conclusion. 